\title{
MOLECULAR DEREPLICATION OF VOLATILE OILS FROM Saururus cernuus L. AND EVALUATION OF ANTI-
} Trypanosoma cruzi ACTIVITY

\author{
Juliana R. Brito ${ }^{\text {a }}$ Thais A. Costa-Silva ${ }^{\mathrm{b}}$, Vinicius S. Londero ${ }^{\mathrm{a}}$, João L. Baldim ${ }^{\mathrm{c}}$, Andre G. Tempone ${ }^{\mathrm{d}}$, Edgard A. Ferreira ${ }^{\mathrm{e}, \#}$ \\ and João Henrique G. Lago ${ }^{\mathrm{b}, *, \mathbb{D}}$ \\ anstituto de Ciências Ambientais, Químicas e Farmacêuticas, Universidade Federal de São Paulo, 09972-270 Diadema - SP, Brasil \\ ${ }^{b}$ Centro de Ciências Naturais e Humanas, Universidade Federal do ABC, 09210-180 Santo André - SP, Brasil \\ 'Instituto Federal de Educação, Ciências e Tecnologia do Sul de Minas Gerais, 37890-000 Muzambinho - MG, Brasil \\ ${ }^{d}$ Centro de Parasitologia e Micologia, Instituto Adolfo Lutz, 01246-902 São Paulo - SP, Brasil

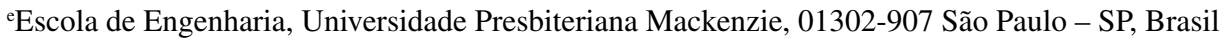

Recebido em 25/05/2021; aceito em 20/07/2021; publicado na web em 20/08/2021

\begin{abstract}
The present study reports the molecular dereplication and the evaluation of anti-Trypanosoma cruzi activity of volatile oils from inflorescences, leaves, branches, and roots of Saururus cernuus L. (Saururaceae). Chemically, the oils showed the predominance of sesquiterpenes in inflorescences $(64.04 \%)$ and branches $(63.82 \%)$, with $\beta$-sesquiphellandrene $(25.50 \%)$ and $(E)$-caryophyllene (22.40\%) corresponding to the main constituents of each oil. Furthermore, it was possible to detect safrole as the most predominant compound in the leaves oil (49.09\%). On the other hand, the oil from roots was mainly composed by monoterpenes $(84.60 \%)$, with limonene in higher concentration (38.41\%), followed by $\alpha$-pinene $(20.19 \%)$, and camphene $(14.71 \%)$. The oils from inflorescences and branches displayed higher antitrypanosomal potency with $\mathrm{EC}_{50}$ values of 7.1 and $8.8 \mu \mathrm{g} \mathrm{mL}^{-1}$, respectively, followed by the oils from the roots and inflorescences, with $\mathrm{EC}_{50}$ values of 17.3 and $30.4 \mu \mathrm{g} \mathrm{mL} \mathrm{L}^{-1}$, respectively. Additionally, branches and inflorescences oils displayed no toxicity in mammalian NCTC cells $\left(\mathrm{CC}_{50}>200 \mu \mathrm{g} \mathrm{mL}{ }^{-1}\right)$. Using two PLS-DA methods, it was possible to suggest that the anti-T. cruzi activity of the tested oils could be associated with the presence of $\beta$-sesquiphellandrene, safrole, $\beta$-elemene, and $\alpha$-zingiberene whereas threo-austrobailignan-5, $\beta$-sesquiphellandrene, $\alpha$-humulene, germacrene $\mathrm{D}$, and bicyclogermacrene play a role in the cytotoxicity against NCTC cells.
\end{abstract}

Keywords: Saururus cernuus; volatile oils; terpenes; safrol; Trypanosoma cruzi.

\section{INTRODUCTION}

Phytochemical studies conducted with species from Saururaceae have been shown a wide diversity of natural products, ${ }^{1-7}$ which are associated with biological properties such as anti-inflammatory, anti-tumoral, anti-osteoporotic, and hepatoprotective activities. ${ }^{8-12}$ Belonging to Saururaceae, Saururus cernuus L. is an ornamental plant with worldwide distribution but native to eastern North America, where is known as lizard's tail, water-dragon, or dragon's tail. In folk medicine, the roots of this plant have been used in the treatment of rheumatism and as poultice for healing skin wounds. The infusion of leaves has also been used for the treatment of back and breast pains as well as for treating stomach ailments. ${ }^{13}$ Chemically, S. cernuus is composed by lignans, alkaloids and terpenoids with antiviral, ${ }^{14}$ antiinflammatory ${ }^{15}$ and antitumoral ${ }^{9,16}$ activities.

The composition of $S$. cernuus volatile oils was demonstrated in a previous study ${ }^{17}$ with the identification of mono and sesquiterpenes from its aerial parts, with $\beta$-bisabolene as the main component. Although several phytochemical studies have been described, no antiprotozoal potential was evaluated to date, with exception to the occurrence of antileishmanial and antitrypanosomal neolignans isolated from leaves. ${ }^{18,19}$

American trypanosomiasis, also known as Chagas disease, is caused by the protozoan Trypanosoma cruzi. The disease is endemic in Latin America causing around 14,000 deaths per year, according to the Drugs for Neglected Disease Initiative - DNDi. ${ }^{20}$ The clinical treatment is currently based on two drugs (nifurtimox

*e-mail: joao.lago@ufabc.edu.br

\#alternative e-mail: edgard.ferreira@mackenzie.br and benznidazole), with severe side effects and reduced efficacy. ${ }^{21,22}$ In this context, whereas available drugs are quite unsatisfactory, it is necessary a constant search for the development of prototypes to development of new chemotherapeutic agents for the treatment of the Chagas disease. As part of our continuous study concerning the discovery of natural products with antitrypanosomal activity, ${ }^{23,24}$ the present work aimed to analyze the chemical composition and evaluation of the antitrypanosomal potential and mammalian cytotoxicity of the volatile oils from inflorescences, flowers, branches and roots of $S$. cernuus. In addition, two partial least squares discriminant analysis (PLS-DA) methods were built to explore and identify promising compounds associated to the antiparasitic activity of $S$. cernuus volatile oils.

\section{EXPERIMENTAL}

\section{Plant material}

Leaves, branches, roots and inflorescences of $S$. cernuus were collected on August, 2019 in Suzano City, São Paulo State, Brazil, from a producer of ornamental plants and received a registration code at SISGEN A4123E4. After botanical identification, a voucher specimen (E.A. Ferreira - 001) has been deposited at Herbarium of the Institute of Biosciences of the University of São Paulo (SPF).

\section{Volatile oils extraction}

The fresh plant material - leaves $(400 \mathrm{~g})$, branches $(400 \mathrm{~g})$, roots (400 g), and inflorescences ( $5 \mathrm{~g}$ ) - were individually subjected to hydrodistillation in Clevenger apparatus for a period of five hours, in 
triplicate. After this period, the obtained oils were extracted with ethyl ether $(3 \mathrm{X} 3 \mathrm{~mL})$, dried over anhydrous $\mathrm{Na}_{2} \mathrm{SO}_{4}$, filtered, concentrated under reduced pressure, and were kept at $-20{ }^{\circ} \mathrm{C}$ for further analysis. The yield for each volatile oil was calculated using the equation $\mathrm{Y}(\%)=\mathrm{M}_{\mathrm{O}} / \mathrm{M}_{\mathrm{Fm}} \mathrm{X} 100$, where $\mathrm{M}_{\mathrm{O}}$ is the mass of the extracted oil $(\mathrm{g})$ and $\mathrm{M}_{\mathrm{Fm}}$ is the mass of fresh plant material $(\mathrm{g})$.

\section{Molecular dereplication}

Identification and quantification analysis of volatile oils were performed, in triplicates, using an Agilent 7890A GC gas chromatograph coupled to a 5975C MSD (Mass Selective Detector) equipped with a HP-5 fused silica capillary column $(30 \mathrm{~m} \times 0.25$ $\mathrm{mm}, 0.25 \mu \mathrm{m}$ film thickness). Helium was used as carrier gas with a flow rate of $1.0 \mathrm{~mL} \mathrm{~min}^{-1}$. Ionization energy was $70 \mathrm{eV}$ and mass range detection from 40 to $500 \mathrm{Da}$. An automatic sampler (Agilent G4513A) was used for injection of $0.1 \mu \mathrm{L}$ per sample, varying the split mode according to the plant tissues (leaves - 100:1; roots - 50:1; branches - 75:1; inflorescences - 5:1). The injector temperature was set at $260{ }^{\circ} \mathrm{C}$. Initially the column temperature was maintained at $60{ }^{\circ} \mathrm{C}$ for $4 \mathrm{~min}$, then gradually raised at a rate of $3{ }^{\circ} \mathrm{C} \mathrm{min}^{-1}$ to $280{ }^{\circ} \mathrm{C}$ and then maintained at this temperature for $3 \mathrm{~min}$. The identification of compounds was based on two methods: comparison of their mass spectra with data in NIST 11 (National Institute of Standards and Technologies, Mass Spectra Libraries) and by calculating arithmetic indexes (AI), determined relative to the retention times of a sequence of $n$-alkanes $\left(\mathrm{C}_{8}-\mathrm{C}_{20}\right)$, followed by comparison of obtained values with those reported in the literature. ${ }^{25,26}$

\section{Determination of antitrypanosomal activity}

Volatile oils from inflorescences, leaves, branches and roots of $S$. cernuus were individually dissolved in DMSO, diluted in culture medium and incubated with the parasites to determine the respective $\mathrm{EC}_{50}$ (50\% Effective Concentration) values. Briefly, each volatile oil was serially diluted (150 to $1.17 \mu \mathrm{g} \mathrm{mL}^{-1}$ - eight different concentrations) using RPMI-1640 medium in 96-well plates, and then trypomastigote forms of $T$. cruzi were added at a concentration of $1 \times 10^{6}$ parasites/well. Plates were kept at $37{ }^{\circ} \mathrm{C}$ at $5 \% \mathrm{CO}_{2}$ for $24 \mathrm{~h}$. After this period, to determine the viability of the parasites, $20 \mu \mathrm{L}$ of $10 \%$ resazurin were added and the plates were incubated for another $20 \mathrm{~h}$ under the same conditions. The optical density was determined in Filter Max F5 (Multi-Mode Microplate Reader) at $570 \mathrm{~nm} .{ }^{27}$ The standard drug benznidazole was used as positive control while untreated cells (without volatile oils samples) were used as negative control.

\section{Determination of cytotoxicity}

$\mathrm{CC}_{50}$ (50\% Cytotoxic Concentration) values were determined in NCTC cells (clone 929) using the colorimetric method of MTT. ${ }^{28}$ Briefly, $6 \times 10^{4}$ cells/well were incubated with each volatile oil, serially diluted (200 to $1.56 \mu \mathrm{g} \mathrm{mL}^{-1}$ - eight different concentrations) in RPMI - 1640 medium and 10\% SFB in 96-well plates. Then, the cells were incubated for $48 \mathrm{~h}$ at $37{ }^{\circ} \mathrm{C}$ with $5 \% \mathrm{CO}_{2}$. The optical density was measured in FilterMax F5 (Molecular Devices) at $570 \mathrm{~nm}$. To determine the cytotoxicity of each volatile oil with effective antiprotozoal activity, the Selectivity Indexes (SI) was calculated using the following expression: $\mathrm{SI}=\mathrm{CC}_{50} / \mathrm{EC}_{50}$.

\section{Statistical analysis}

$\mathrm{EC}_{50}$ and $\mathrm{CC}_{50}$ data represent the mean of three independent representative assays tested in duplicate and were calculated using sigmoid dose-response curves in Graph-Pad Prism 6.0 software.

\section{Investigation of promising compounds using partial least squares - discriminant analysis (PLS-DA)}

Two PLS-DA methods were built using an in-house dataset associating compounds, the percentage of occurrence, and their respective source (inflorescences, branches, leaves or roots). Analysis were performed by the development of two supervised methods using the web-based platform Metaboanalyst ${ }^{29}$ based on concentration of compounds and values of $\mathrm{EC}_{50}$ and $\mathrm{CC}_{50}$, respectively, for T. cruzi and NCTC cells. Two groups were created for the $\mathrm{EC}_{50}$ analysis where the volatile oils of leaves, branches and roots were considered actives (EC Ev $_{5}$ values: $7.1 \pm 3.3 \mu \mathrm{g} \mathrm{mL}^{-1} ; 8.8 \pm 4.7 \mu \mathrm{g} \mathrm{mL}^{-1} ; 17.3 \pm 1.5 \mu \mathrm{g} \mathrm{mL}{ }^{-1}$, respectively) whereas inflorescences oil was considered inactive $\left(\mathrm{EC}_{50}\right.$ value: $30.4 \pm 0.5 \mu \mathrm{g} \mathrm{mL} \mathrm{m}^{-1}$ ). The standard drug benznidazole was used as a positive control and resulted in an $\mathrm{EC}_{50}$ value of $12.4 \pm 0.8 \mu \mathrm{g} \mathrm{mL}{ }^{-1}$. Two groups were created for the $\mathrm{CC}_{50}$ values analysis where the volatile oils of inflorescences and branches were considered nontoxic $\left(\mathrm{CC}_{50}\right.$ values $\left.>200 \mu \mathrm{g} \mathrm{mL}^{-1}\right)$ and the volatile oils of leaves and roots were considered toxic $\left(\mathrm{CC}_{50}\right.$ values $\left.<200 \mu \mathrm{g} \mathrm{mL}^{-1}\right)$. These classes were created based on the $\mathrm{CC}_{50}$ value of the standard compound benznidazole $\left(<200 \mu \mathrm{g} \mathrm{mL} \mathrm{m}^{-1}\right)$. The two PLS-DA methods were built using three components that explained at least $75 \%$ of the model variance. Validation values for $\mathrm{EC}_{50}$ : component $1-69.0 \%$; component $2-16.2 \%$; component $3-14.8 \%$. Accuracy $-0.75 ; 1$; and 1 (for components 1,2 and 3 , respectively). $\mathrm{R}^{2}-0.3 ; 0.93$; and 1 (for components 1,2 and 3 , respectively), $\mathrm{Q}^{2}-0.15 ; 0.84$; and 1.0 (for components 1, 2 and 3, respectively). Validation values for $\mathrm{CC}_{50}$ : component $1-60.2 \%$; component $2-32.7 \%$; component $3-7.1 \%$. Accuracy $-0.75 ; 1$; and 1 (for components 1, 2 and 3, respectively), $\mathrm{R}^{2}-0.60$; 0.97; and 1 (for components 1, 2 and 3, respectively); $\mathrm{Q}^{2}-0.34 ; 0.96$; and 1 (for components 1, 2 and 3, respectively). The results of coefficients to the classes were used in order to correlate promising compounds to each biological activity. The validation values for both methods suggest that important information can be retrieved from this analysis. ${ }^{30}$

\section{RESULTS AND DISCUSSION}

Hydrodistillation of leaves, branches, roots and inflorescences of $S$. cernuus, afforded volatile oils with yields of $0.01,0.01,0.01$ and $0.04 \%$, respectively.

As could be seen in Table 1, 46 compounds were identified distributed in monoterpenes, phenylpropanoids and sesquiterpenes besides other minor metabolites. Inflorescences and leaves oils showed a reduced diversity of volatile compounds - nine and 18 compounds, respectively, corresponding to $93.95 \%$ and $96.53 \%$ of the total identified. On the other hand, in the branches and roots oils were observed a higher metabolic diversity with 28 (94.69\%) and 27 $(97.77 \%)$ compounds, respectively.

Sesquiterpenes were detected in high concentration compounds in all studied oils, except that from roots, with emphasis on inflorescences $(64.04 \%)$ and branches $(63.82 \%)$. Despite of the amounts of sesquiterpenes in the leaves oil $(40.33 \%)$, the phenylpropanoids were found as predominant compounds $(52.22 \%)$. On the other hand, the oil from roots showed to be composed mainly by monoterpenes (84.60\%). Analyzing the relative percentage of each component in the studied oils, those obtained from inflorescences and leaves were composed mainly by $\beta$-sesquiphellandrene (25.50 and $18.3 \%$ ) and safrole (23.21 and $49.09 \%$ ), respectively, being this phenylpropanoid also detected in high amounts in branches $(18.89 \%)$ but absent in roots 
Table 1. Relative percentage of components of volatile oils from leaves, branches, roots and inflorescences of S. cernuus

\begin{tabular}{|c|c|c|c|c|c|}
\hline Compound & $\mathrm{AI}$ & Inflorescences & Leaves & Branches & Roots \\
\hline$\alpha$-pinene & 932 & - & - & $1.43 \pm 0.02$ & $20.19 \pm 0.03$ \\
\hline camphene & 946 & - & - & $0.61 \pm 0.01$ & $14.71 \pm 0.01$ \\
\hline$\beta$-pinene & 974 & - & - & $0.20 \pm 0.02$ & $1.50 \pm 0.02$ \\
\hline myrcene & 988 & - & - & $0.22 \pm 0.01$ & $1.92 \pm 0.01$ \\
\hline$\alpha$-phellandrene & 1002 & - & - & - & $1.51 \pm 0.01$ \\
\hline$o$-cymene & 1022 & - & - & - & $0.63 \pm 0.01$ \\
\hline limonene & 1024 & - & - & $0.83 \pm 0.02$ & $38.41 \pm 0.03$ \\
\hline$(Z)-\beta$-ocimene & 1032 & - & $0.39 \pm 0.02$ & $0.70 \pm 0.01$ & - \\
\hline$(E)$ - $\beta$-ocimene & 1033 & - & $1.01 \pm 0.01$ & $1.21 \pm 0.02$ & $0.61 \pm 0.02$ \\
\hline 4-carene & 1046 & - & - & - & $0.69 \pm 0.03$ \\
\hline linalool & 1095 & - & $1.87 \pm 0.02$ & $0.89 \pm 0.02$ & - \\
\hline camphor & 1141 & - & - & $0.28 \pm 0.03$ & - \\
\hline estragole & 1195 & - & $0.73 \pm 0.01$ & - & - \\
\hline decanal & 1201 & - & $0.40 \pm 0.02$ & - & - \\
\hline methyl thymol & 1232 & - & - & - & $0.42 \pm 0.01$ \\
\hline decanol & 1266 & - & $0.31 \pm 0.01$ & - & - \\
\hline isobornyl acetate & 1283 & - & - & - & $4.01 \pm 0.00$ \\
\hline safrole & 1285 & $23.21 \pm 0.02$ & $49.09 \pm 0.02$ & $18.89 \pm 0.02$ & - \\
\hline$\beta$-elemene & 1389 & $12.01 \pm 0.01$ & $4.31 \pm 0.02$ & $6.61 \pm 0.01$ & $0.41 \pm 0.01$ \\
\hline (E)-caryophyllene & 1417 & $9.69 \pm 0.01$ & $4.51 \pm 0.03$ & $22.40 \pm 0.02$ & $5.20 \pm 0.03$ \\
\hline trans- $\alpha$-bergamotene & 1432 & - & - & $0.21 \pm 0.01$ & - \\
\hline aromandendrene & 1439 & - & - & - & $0.23 \pm 0.01$ \\
\hline$\alpha$-humulene & 1452 & $3.31 \pm 0.03$ & $1.71 \pm 0.03$ & $7.09 \pm 0.02$ & $0.91 \pm 0.02$ \\
\hline$(E)$ - $\beta$-farnesene & 1454 & $1.14 \pm 0.01$ & $1.45 \pm 0.04$ & $1.20 \pm 0.01$ & - \\
\hline$\alpha$-elemene & 1462 & - & - & $0.81 \pm 0.02$ & - \\
\hline$\gamma$-muurolene & 1478 & - & - & - & $0.19 \pm 0.02$ \\
\hline germacrene D & 1484 & $5.91 \pm 0.04$ & $3.71 \pm 0.02$ & $7.14 \pm 0.01$ & $1.48 \pm 0.01$ \\
\hline$\beta$-selinene & 1489 & - & - & $0.73 \pm 0.02$ & - \\
\hline bicyclogermacrene & 1500 & - & - & $5.92 \pm 0.01$ & $2.82 \pm 0.02$ \\
\hline$\alpha$-zingiberene & 1493 & $6.48 \pm 0.01$ & $5.21 \pm 0.03$ & - & - \\
\hline 4,5-di-epi-aristolochene & 1471 & - & - & $0.29 \pm 0.00$ & - \\
\hline methyl $E$-isoeugenol & 1491 & - & - & - & $0.13 \pm 0.01$ \\
\hline$E, E$ - $\alpha$-farnesene & 1505 & - & - & $0.27 \pm 0.01$ & - \\
\hline$\beta$-bisabolene & 1505 & - & $0.42 \pm 0.00$ & - & - \\
\hline$\delta$-amorphene & 1511 & - & - & - & $0.21 \pm 0.02$ \\
\hline$\delta$-cadinene & 1513 & - & - & - & $1.05 \pm 0.04$ \\
\hline$\beta$-sesquiphellandrene & 1521 & $25.50 \pm 0.02$ & $18.27 \pm 0.01$ & $7.63 \pm 0.02$ & - \\
\hline (E)-nerolidol & 1561 & - & $0.31 \pm 0.02$ & $0.33 \pm 0.01$ & - \\
\hline spathulenol & 1577 & - & - & $0.41 \pm 0.02$ & $0.24 \pm 0.01$ \\
\hline eremophilene & 1589 & - & - & $0.32 \pm 0.03$ & $0.13 \pm 0.00$ \\
\hline$(Z)$-asarone & 1616 & - & - & - & $0.24 \pm 0.02$ \\
\hline$\beta$-eudesmol & 1649 & - & - & $0.45 \pm 0.01$ & $0.31 \pm 0.02$ \\
\hline$\tau$-muurolol & 1650 & - & - & $2.01 \pm 0.02$ & - \\
\hline$\alpha$-cadinol & 1652 & - & $0.43 \pm 0.01$ & - & $0.40 \pm 0.01$ \\
\hline$(E)$-asarone & 1675 & - & - & - & $0.22 \pm 0.02$ \\
\hline \multirow[t]{7}{*}{ threo-austrobailignan-5 } & 2054 & $6.70 \pm 0.01$ & $2.40 \pm 0.02$ & $5.61 \pm 0.03$ & - \\
\hline & Yield / \% & 0.01 & 0.01 & 0.01 & 0.04 \\
\hline & monoterpenes & - & $3.27 \pm 0.02$ & $6.37 \pm 0.03$ & $84.60 \pm 0.03$ \\
\hline & phenylpropanoids* & $29.91 \pm 0.02$ & $52.22 \pm 0.02$ & $24.50 \pm 0.03$ & $0.13 \pm 0.01$ \\
\hline & sesquiterpenes & $64.04 \pm 0.04$ & $40.33 \pm 0.04$ & $63.82 \pm 0.03$ & $13.04 \pm 0.04$ \\
\hline & other compounds & - & $0.71 \pm 0.02$ & - & - \\
\hline & Total identified & $93.95 \pm 0.04$ & $96.53 \pm 0.04$ & $94.69 \pm 0.03$ & $97.77 \pm 0.04$ \\
\hline
\end{tabular}

*including neolignan 
oil. The sesquiterpenes $(E)$-caryophyllene and $\beta$-elemene were the only compounds found in all studied oils with relative concentrations ranging from $4.51-22.4 \%$ and $0.41-12.01 \%$, respectively. The volatile oil from roots exhibited a different profile being composed, predominantly, by the monoterpenes limonene (38.4\%), $\alpha$-pinene $(20.2 \%)$ and camphene $(14.7 \%)$. It must be highlighted that the occurrence of the neolignan threo-austrobailigan-5, in the inflorescences $(6.70 \%)$, leaves $(2.40 \%)$ and branches $(5.61 \%)$ oils. This compound, biosynthetically related to safrole, was also isolated from the $\mathrm{MeOH}$ extract from leaves of S. cernuus. ${ }^{18}$

In a previous study conducted with aerial parts of $S$. cernuus collected in United States of America, it was observed that the volatile oil is mainly constituted by sesquiterpenes with higher concentration of $\beta$-bisabolene $(12.30 \%)$ and $\alpha$-curcumene $(7.03 \%) .{ }^{17}$ Comparatively, the oil from $S$. chinensis $^{31}$ was predominately composed by sesquiterpenes being $\delta$-cadinol, $\delta$-cadinene and transphytol the main identified compounds, with 22.5, 19.7 and $13.7 \%$, respectively. Considering other species of Saururaceae such as Houttuynia cordata, it was observed the predominance of terpenes and polyketides as volatiles from flowers, leaves, stems, rhizomes, and roots. As reported, the main identified compound in analyzed oils was 4-tridecanone whereas myrcene was the most frequent monoterpene in flowers, leaves and stems, while in rhizomes and roots was detected the predominance of $\beta$-pinene. 1-Decanal was the most common occurring polyketide in the leaves and stems oils but in reduced amounts in flowers, rhizomes and roots oils. ${ }^{32}$ According to the obtained results in the present study, the analyses of volatile oils from different tissues of $S$. cernuus showed an expressive chemical variety in their composition, in accordance with literature, ${ }^{17}$ since the sesquiterpenes were detected as predominant metabolites.

The volatile oils from $S$. cernuus were submitted to evaluation of the in vitro anti- $T$. cruzi activity (trypomastigote forms) and cytotoxicity in mammalian cells (NCTC). The obtained results (Table 2) revealed that the oils were active against the parasite being those obtained from leaves and branches with higher potential $\left(\mathrm{EC}_{50}\right.$ values of 7.1 and $8.8 \mu \mathrm{g} \mathrm{mL} \mathrm{m}^{-1}$, respectively) in comparison to inflorescences and roots oils $\left(\mathrm{EC}_{50}\right.$ values of 17.3 and $30.4 \mu \mathrm{g} \mathrm{mL}^{-1}$, respectively). Considering the cytotoxicity, leaves and roots oils exhibited $\mathrm{CC}_{50}$ values of 39.6 and $66.4 \mu \mathrm{g} \mathrm{mL} \mathrm{m}^{-1}$, respectively, while oils from branches and inflorescences were nontoxic to the highest tested concentration $\left(200 \mu \mathrm{g} \mathrm{mL}^{-1}\right)$. Based on these results, selectivity indexes to the studied oils were calculated as $>6.6$ (inflorescences), 5.6 (leaves), > 22.7 (branches) and 3.8 (roots). Positive control (benznidazole) resulted in an $\mathrm{EC}_{50}$ of $12.4 \mu \mathrm{g} \mathrm{mL}^{-1}$ and a $\mathrm{CC}_{50}>200 \mu \mathrm{g} \mathrm{mL}^{-1}$, with a SI $>16.2$. Based on these results, it was possible to observe that the volatile oil from branches of $S$. cernuus exhibited a similar effect of benznidazole being, thus, relevant for future studies including non-clinical trials aiming at its uses for medicinal purposes.

In order to evaluate the individual components of each studied oil in the anti-T. cruzi activity and mammalian cytotoxicity, the qualitative (chemical composition) and quantitative (relative amount) data were organized as matrices containing instances (source) and attributes (compounds) as $\mathrm{X}$ axis. For each created PLS-DA method, the $\mathrm{Y}$ axis was added as nominal classes (active or inactive and low toxicity or toxic) based on the results of biological assays. This organization was carried out to identify promising compounds associated to the biological activities of volatile oils against the trypomastigote forms of $T$. cruzi. Two approaches were used to suggest important compounds: 1 - coefficients values to the classes (obtained by the PLS-DA results) and 2 - their distribution among sources. Once the method was validated according to the parameters obtained for each dataset (materials and methods section, item 2.6), coefficients values were obtained. Several components were associated to the active and inactive classes. The first four, and more important compounds, given the coefficient value to the method were $\beta$-sesquiphellandrene (highly correlated to the inactive class - Coeff. Value: 100), safrole (highly correlated to the active class - Coeff. Value: 87.3), $\beta$-elemene (highly correlated to the inactive class Coeff. Value: 54.8 ), and $\alpha$-zingiberene (highly correlated to the inactive class - Coeff. Value: 25.9), as showed in Figure 1. Additional compounds associated with anti-T. cruzi activity were also suggested, such as $(E)$-caryophyllene, bicyclogermacrene, limonene, $\alpha$-pinene, linanol, $(E)$ - $\beta$-ocimene, and camphene.

The concentration of each compound based on their classification exhibits that the active volatile oils contain lower percentages of $\beta$-sesquiphellandrene. On the other hand, higher concentrations of safrole as well as lower concentrations of $\beta$-elemene and $\alpha$-zingiberene were associated to better $\mathrm{EC}_{50}$ values against trypomastigotes of T. cruzi (Figure 1). Considering the cytotoxicity, several compounds were suggested as important for the classification of volatile oils. The first four and more important compounds, given the coefficient value to the method, were limonene (highly correlated to increased toxicity - Coeff. Value: 100), safrole (highly correlated to increased cytotoxicity values - Coeff. Value: 95.5), (E)-caryophyllene (highly correlated to decreased toxicity - Coeff. Value: 69.3), and $\beta$-elemene (highly correlated to decreased cytotoxicity - Coeff. Value: 46.7), as showed in Figure 2. Additional compounds associated to the reduced cytotoxicity, with lower coefficient values, were also suggested, such as threo-austrobailignan-5, $\beta$-sesquiphellandrene, $\alpha$-humulene, germacrene $\mathrm{D}$, and bicyclogermacrene.

The concentration of each compound based on their classification allowed identification of important compounds in volatile oils with higher $\mathrm{CC}_{50}$ values, e.g., lower cytotoxicity against NCTC cells. The results showed that the decrease in cytotoxicity is associated with oils containing lower concentrations of limonene and safrole. According to the method, higher concentrations of limonene are associated to the toxicity. On the other hand, higher concentrations of $(E)$-caryophyllene and $\beta$-elemene are present in samples with lower cytotoxicity.

Volatile oils are mixtures of compounds which can exhibit synergism, antagonism, or additive effects in biological assays. ${ }^{33}$

Table 2. Anti-T. cruzi and cytotoxicity activities of volatile oils from different tissues of S. cernuus

\begin{tabular}{|c|c|c|c|}
\hline plant material volatile oil & $\begin{array}{c}\text { T. cruzi } \\
\mathrm{EC}_{50}\left(\mu \mathrm{g} \mathrm{mL}^{-1}\right) \pm \mathrm{SD}\end{array}$ & $\begin{array}{c}\mathrm{NCTC} \\
\mathrm{CC}_{50}\left(\mu \mathrm{g} \mathrm{mL}^{-1}\right) \pm \mathrm{SD} \\
\end{array}$ & SI \\
\hline inflorescences & $30.4 \pm 0.5$ & $>200$ & $>6.6$ \\
\hline leaves & $7.1 \pm 3.3$ & $39.6 \pm 11.7$ & 5.6 \\
\hline branches & $8.8 \pm 4.7$ & $>200$ & $>22.7$ \\
\hline roots & $17.3 \pm 1.5$ & $66.4 \pm 6.7$ & 3.8 \\
\hline benznidazole & $12.4 \pm 0.8$ & $>200$ & $>16.2$ \\
\hline
\end{tabular}

$\mathrm{EC}_{50}: 50 \%$ effective concentration; $\mathrm{CC}_{50}: 50 \%$ cytotoxic concentration; SI: selectivity index; \pm SD: standard deviation; 

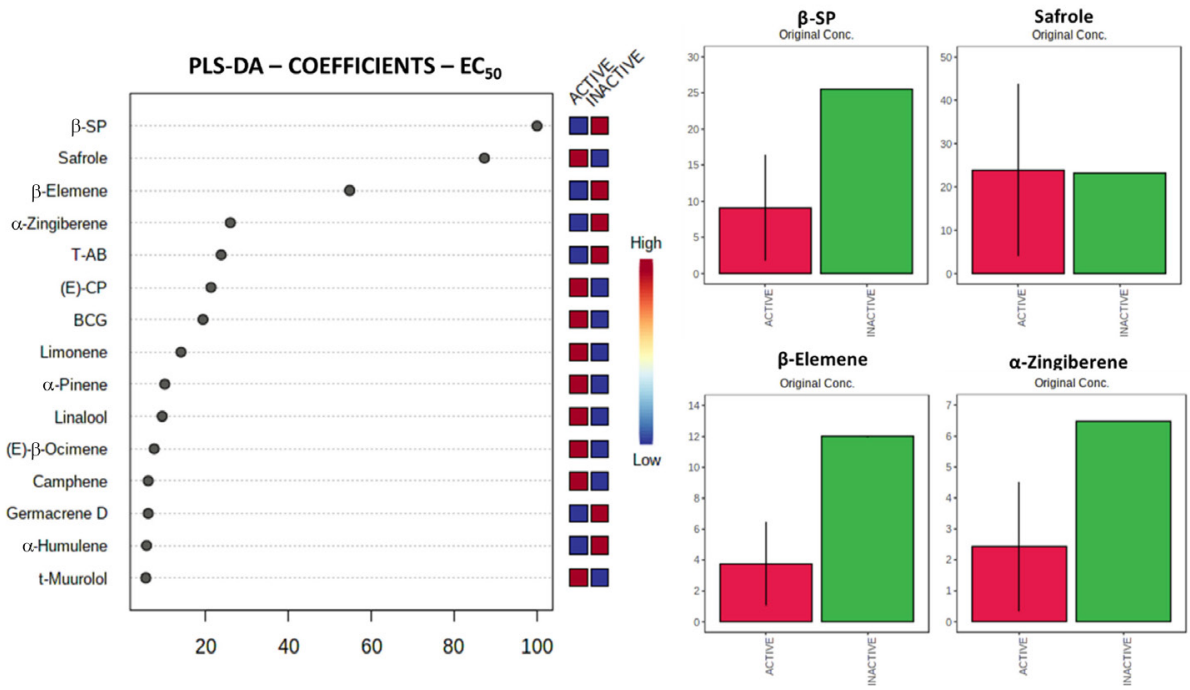

Figure 1. Coefficient values obtained from the PLS-DA method and the first four compounds exhibiting high coefficients to the classes for EC 50 . The first four compounds have their average concentrations among classes exhibited. Abbreviations: $b$-SP - $\beta$-sesquiphellandrene, T-AB - Threo-austrobailignan-5, $E-C P-(\mathrm{E})$-caryophyllene, $B C G$ - bicyclogermacrene
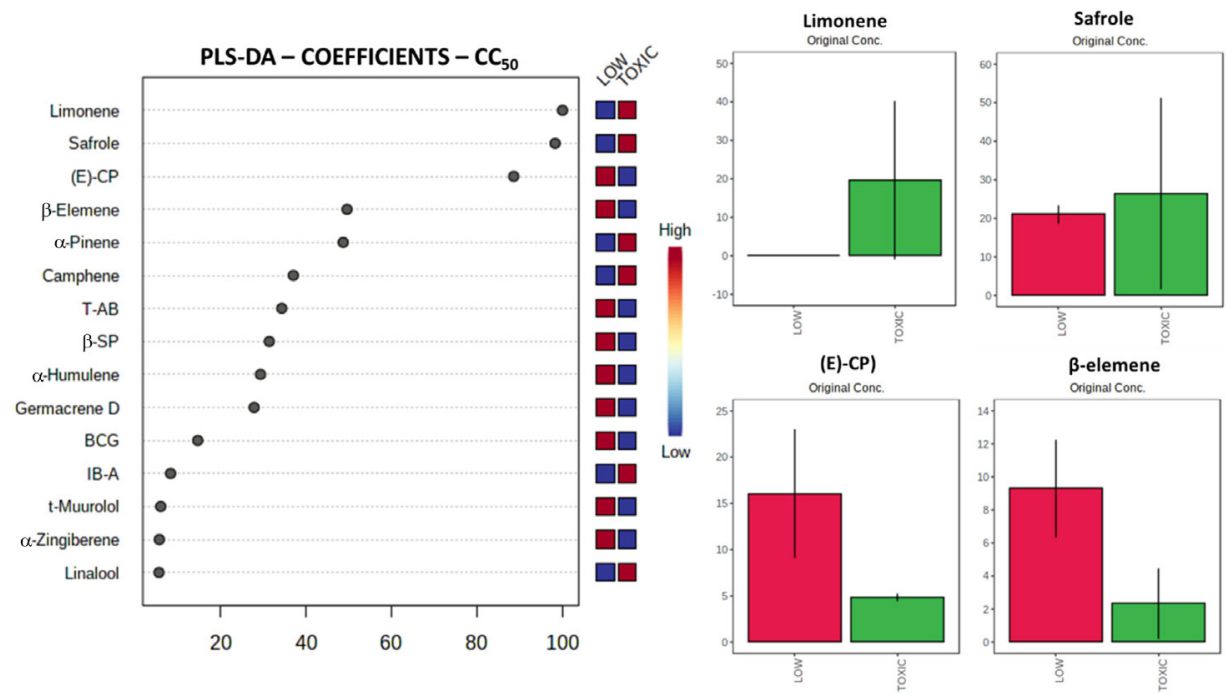

Figure 2. Coefficient values obtained from the PLS-DA method and the first four compounds exhibiting high coefficients to the classes for CC 50 . The first four compounds have their average concentrations among classes exhibited. Abbreviations: $b$-SP - $\beta$-sesquiphellandrene, E-CP - (E)-caryophyllene, $B C G$ - bicyclogermacrene, $T$ - $A B$ - Threo-austrobailignan-5, IB-A - Isobornyl acetate

The influence and interpretation of each compound is complex in this scenario. In this sense, the use of multivariate statistical analysis, resembling discriminant approaches could suggest patterns that point to promising compounds in the entire composition.

\section{CONCLUSIONS}

Chemical analysis of volatile oils from different parts of $S$. cernuus showed the predominance of sesquiterpenes in the inflorescences and branches, in which $\beta$-sesquiphellandrene and $(E)$-caryophyllene were the main compounds. It was also possible to detect phenylpropanoid derivatives, especially safrole, being one of the most predominant compounds in these tissues. On the other hand, the roots oil was predominantly composed by monoterpenes, with limonene, $\alpha$-pinene, and camphene as main compounds. The presence of the threo-austrobailigan-5, a neolignan biosynthetically related to safrole, was also detected in inflorescences, leaves and branches. In addition, these oils showed different activities against trypomastigotes of $T$. cruzi, as well as toxicity against NCTC mammalian cells, indicated a promising antiparasitic source of bioactive molecules. The use of PLS-DA methods suggested that the anti-T. cruzi activity of tested oils could be associated to the presence of $\beta$-sesquiphellandrene, safrole, $\beta$-elemene and $\alpha$-zingiberene whereas threo-austrobailignan-5, $\beta$-sesquiphellandrene, $\alpha$-humulene, germacrene $\mathrm{D}$, and bicyclogermacrene play a role in the cytotoxicity against NCTC cells. Therefore, our findings support a future application of these plant materials, especially the volatile oil from branches, for the development of new prototypes for the treatment of Chagas disease.

\section{ACKNOWLEDGEMENTS}

The authors are grateful to FAPESP (2021/02789-7, 2018/078851, and 2018/10279-6) and MackPesquisa (151024) for the financial support for the development of this work. J.R.B., A.G.T. and J.H.G.L. thank CAPES and CNPq for fellowships. 


\section{REFERENCES}

1. Rao, K. V.; Alvarez, F. M.; J. Nat. Prod. 1982, 45, 393.

2. Rao, K.V.; Puri, V. N.; Diwan, P.K.; Alvarez, F. M.; Pharm. Res. Commun. 1987, 19, 629.

3. Rao, K. V.; Reddy, G. C. S.; J. Nat. Prod. 1990, 53, 309.

4. Rao, K. V.; Rao, N. S. P.; J. Nat. Prod. 1990, 53, 212.

5. Rao, K. V.; Oruganty, R. S.; J. Liq. Chromat. Relat. Technol. 1997, 20, 3121.

6. Bauer, R.; Pröbstle, A.; Lotter, H.; Wagner-Redecker, W.; Matthiesen, U.; Phytomedicine 1996, 2, 305.

7. Kim, S. K.; Ryu, S. Y.; No, J.; Choi, S. U.; Kim, Y. S.; Arch. Pharm. Res. 2001, 24, 518 .

8. Lee, E.; Haa, K.; Yook, J. M.; Jin, M. H.; Seo, C. S.; Son, K. H.; Kim, H. P.; Bae, K. H.; Kang, S. S.; Son, J. K.; Chang, H. W.; Biol. Pharm. Bull. 2006, 29, 211.

9. Hodges, T. W.; Hossain, C. F.; Kim, Y. P.; Zhou, D. G.; Nagle, J.; J. Nat. Prod. 2004, 67, 767.

10. Gao, Y.; Hongyu, Z.; Li, Y.; J. Biochem. Mol. Toxicol. 2018, 32, e22033.

11. Wang, L.; Cheng, D.; Wang, H.; Di, L.; Zhou, X.; Xu, T.; Yang, X.; Liu, Y.; J. Ethnopharmacol. 2009, 126, 491.

12. Liu, G.; Zhao, Z.; Shen, M.; Zhao, X.; Xie, J.; He, X.; Li, C.; Am. J. Chin. Med. 2020, $48,47$.

13. Parker, J. D.; Caudill, C. C.; Hay, M. E.; Oecologia 2007, 151, 616.

14. Cui, H.; Xu, B.; Wu, T.; Xu, J.; Yuan, Y.; Gu, Q.; J. Nat. Prod. 2014, 77, 100 .

15. Lee, A. K.; Sung, S. H.; Kim, Y. C.; Kim, S. G.; Br. J. Pharmacol. 2003, 139, 11.

16. Brito, J. R.; Camilo, F. F.; Figueiredo, C. R.; Azevedo, R. A.; Romoff, P.; Buturi, F. O. S.; Fávero, O. A.; Lago, J. H. G.; Ferreira, E. A.; Quim. Nova 2018, 41, 778.

17. Tutupalli, L. V.; Brown, J. K.; Chaubal, M. G.; Phytochemistry 1975, 14, 595.

18. Brito, J. R.; Passero, L. F. D.; Bezerra-Souza, A.; Laurenti, M. D.; Romoff, P.; Barbosa, H.; Ferreira, E. A.; Lago, J. H. G.; J. Pharm. Pharmacol. 2019, 71, 1871.
19. Brito, J. R.; Costa-Silva, T. A.; Tempone, A. G.; Ferreira, E. A.; Fitoterapia 2019, 137, 104251.

20. Ioset, J. R.; Brun, R.; Wenzler, T.; Kaiser, M; Yardley, V.; Drug screening for kinetoplastids diseases. A Training Manual for Screening in Neglected Diseases 2009, available at https://dndi.org/wp-content/ uploads/2009/04/kinetoplastid_drug_screening_manual_final.pdf, accessed August 2021.

21. Paucar, R.; Moreno-Viguri, E.; Pérez-Silanes, S.; Curr. Med. Chem. 2016, 23, 3154 .

22. Tiwari, N.; Gedda, M. R.; Tiwari, V. K.; Singh, S. P.; Singh, R. K.; Mini Rev. Med. Chem. 2017, 18, 26.

23. Conserva, G. A. A.; Quiros-Guerrero, L. M.; Costa-Silva, T.; Marcourt, L.; Pinto, E.G.; Tempone, A. G.; Fernandes, J. P. S.; Wolfender, J.; Queiroz, E. F.; Lago, J. H. G.; PLoS One 2021, 16, e0247334.

24. Londero, V. S.; Costa-Silva, T.; Antar, G. M.; Batista Junior, J. M.; Baitello, J. B. ; Oliveira, L. V. F. ; Camilo, F. F.; Batista, A. N. L.; Tempone, A. G.; Lago, J. H. G.; J. Nat. Prod. (2021), doi: 10.1021/acs. jnatprod.0c01303.

25. Adams, R. P.; Identification of essential oil components by gas chromatography/mass spectrometry. $4^{\mathrm{a}}$ ed., Allured Publishing: Carol Stream, 2017.

26. Van Den Dool, H.; Kratz, P. D.; J. Chromatogr. A 1963, 11, 463.

27. Gehrke, S. S.; Pinto, E. G.; Steverding, D.; Pleban, K.; Tempone, A. G.; Hider, R. C.; Wagner, G. K.; Bioorg. Med. Chem. 2015, 21, 805.

28. Tada, H.; Shiho, O.; Kuroshima, K.; Koyama, M.; Tsukamoto, K.; J. Immunol. Meth. 1986, 93, 157.

29. Chong, J.; Wishart, D. S.; Xia, J.; Curr. Protoc. Bioinf. 2019, 68, 1.

30. Baldim, J. L.; Alcântara, B. G. V.; Domingos, O. S.; Soares, M. G.; Caldas, I. S.; Novaes, R. D.; Oliveira, T. B.; Lago, J. H. G.; ChagasPaula, D. A.; Oxid. Med. Cell. Longevity 2017, 2017, 3789856.

31. Kim, C.; Lee, S. J.; Hyun, C. G., Lee, N. H.; Int. J. Pharmacol. 2013, 9 , 258.

32. Asakawa, Y.; Tomiyama, K.; Sakurai, K.; Kawakami, Y.; Yaguchi, Y.; J. Oleo Sci. 2017, 66, 889.

33. Caesar, L. K.; Cech, N. B.; Nat. Prod. Rep. 2019, 36, 869. 